\title{
Isolation and cytotoxicity of triterpenes from the roots of Phyllanthus pulcher Wall. ex Müll. Arg. (Euphorbiaceae)
}

\author{
Gururaj Bagalkotkar ${ }^{1}$, Tang Seng Chuan ${ }^{1}$, Shaik Ibrahim Khalivulla ${ }^{2}$, Ahmad Sazali Hamzah ${ }^{3}$, \\ Khozirah Shaari $^{2,4}$, Nordin Haji Lajis ${ }^{2,4}$, Mohammad Said Saad ${ }^{5}$ and Johnson Stanslas ${ }^{1,2 \star}$ \\ ${ }^{1}$ Pharmacotherapeutics Unit, Department of Medicine, Faculty of Medicine and Health Sciences, Universiti Putra \\ Malaysia, 43400 Serdang, Selangor, Malaysia. \\ ${ }^{2}$ Laboratory of Natural Products, Institute of Bioscience, Universiti Putra Malaysia, 43400 Serdang, \\ Selangor, Malaysia. \\ ${ }^{3}$ Organic Synthesis Laboratory, Institute of Science, Universiti Teknologi MARA, \\ 40450 Shah-Alam, Selangor, Malaysia. \\ ${ }^{4}$ Department of Chemistry, Faculty of Science, Universiti Putra Malaysia, \\ 43400 - Serdang, Selangor, Malaysia. \\ ${ }^{5}$ Department of Plant Science, Faculty of Agriculture, Universiti Putra Malaysia, 43400 Serdang, Selangor, Malaysia.
}

Accepted 11 January, 2011

The dried powdered roots of Phyllanthus pulcher Wall. ex Müll. Arg. (Euphorbiaceae), were sequentially extracted with dichloromethane (DCM), ethyl acetate (EtOAc) and methanol (MeOH). The extracts were tested for cytotoxic activity against three human cancer cell lines: MCF-7 (breast), NCl-H460 (lung) and DU-145 (prostate). The DCM extract exhibited the strongest cytotoxic activity compared with EtOAc and $\mathrm{MeOH}$ extracts. Hence from the DCM extract, five pentacyclic triterpenes, 3a-acetoxyl-25-hydroxyolean12-en-28-oic acid (1), glochidone (2), 12(13)-dehydro-3a-acetoxyolean-28-oic acid (3), lupanyl acetate (4) and glochidonol (5) were isolated and identified by spectroscopic analyses $\left({ }^{1} \mathrm{H}\right.$ NMR, ${ }^{13} \mathrm{C}$ NMR, FT-IR, UV, DEPT, HMQC, HMBC and HREIMS). This is the first report on the isolation of 4 from a natural source, whereas 1 and 3 have already been isolated from the families Hamamelidaceae and Compositae (Asteraceae), respectively. However this is the first study reporting the presence of 1 and 3 in the Euphorbiaceae family. The isolated tritepenes 1-5 were tested against the three human tumour cell lines as stated above. Only compounds 1 and 5 exhibited cytotoxic activity, 5 being most potent with IC $_{50}$ values ranging $7.5-13.4 \mu \mathrm{g} / \mathrm{mL}(17.1-30.5 \mu \mathrm{M})$.

Key words: Phyllanthus pulcher, triterpenoids, cytotoxic activity, breast cancer, lung cancer, prostate cancer.

\section{INTRODUCTION}

The genus Phyllanthus is widely distributed throughout the tropical and subtropical parts of the world and has

\footnotetext{
*Corresponding author. E-mail: rcxjs@medic.upm.edu.my; jstanslas@yahoo.co.uk. Tel: +603 89472310. Fax: +603 89472759.
}

Abbreviations: DCM, dichloromethane; EtOAc, ethyl acetate; $\mathrm{MeOH}$, methanol; TLC, thin-layer chromatography. been extensively used in Asian traditional medicine (Burkill, 1935). The wide range of its pharmacological activities was discussed in a number of reviews (Unander et al., 1990, 1992; Bagalkotkar et al., 2006). The extensive phytochemical investigations on several Phyllanthus species revealed various bioactive constituents such as alkaloids, lignans, terpenes, flavones and tannins (Matsunga et al., 1993; Foo, 1995; Bila et al., 1996; Houghton et al., 1996; Lee et al., 1996; Zhang et al., 2001, 2002; Chang et al., 2003). In our continued drug discovery programme from natural 
products, screening of a few selected Phyllanthus species led to the identification of Phyllanthus pulcher with strong cytotoxic activity against several cancer cell lines. In Malaysia, P. pulcher is traditionally used for the treatment of stomach-ache and ulceration (Burkill, 1935). Only recently the biological activities of this species have been reported which includes anti-HIV-1 reverse transcriptase and anti-angiogenesis (Eldeen et al., 2010; $\mathrm{Ng}$ et al., 2010). However, there has been no report on the phytochemical investigation of this species. Hence in this article we report for the first time the isolation and structural elucidation of the main bioactive compounds from this plant that are believed to be responsible for the cytotoxic effects on cancer cell lines. These compounds are lupane-type triterpenoids and they share structural similarity to other well known triterpenoids such as betulinic acid and lupeol which were reported to possess good anticancer activity profile in vitro. In addition since there have been no previous reports on the identification of bioactive compounds from the roots of the plant, we believe the present study provides opportunities for researchers interested in developing standardised phytomedicines from this plant. This is necessary as this plant has been used in various traditional medicine systems as mentioned above and development of standardised products would be advantageous for human use.

\section{MATERIALS AND METHODS}

\section{General experimental procedures}

Melting points were determined with Fisher-Johns aluminium heating stage melting point apparatus equipped with adjustable magnifier model 12-144 and are uncorrected. Optical rotations were measured with a JASCO DIP-370 digital polarimeter. UV spectra were obtained with a CARY 50 Conc UV-Visible spectrophotometer (Varian). The IR spectra were recorded on a Perkin Elmer RXI FTIR spectrophotometer. The EIMS spectra were recorded on a Thermo Finnigan-POLARISQ mass spectrometer, with ionization induced by electron impact at $70 \mathrm{ev}$. HREIMS were measured on Finnigan/MAT 95XL-T Nier-Johnson geometry mass spectrometer. ${ }^{1} \mathrm{H}$ and ${ }^{13} \mathrm{C}$ NMR spectra were obtained on a Varian unity INOVA$500 \mathrm{MHz}$ NMR spectrometer. 2D NMR $\left({ }^{1} \mathrm{H}-{ }^{1} \mathrm{H}\right.$ COSY, HSQC, HMBC and DEPT) spectra were recorded using standard pulse sequences. Column chromatography separations were carried out using Merck silica gel (230-400 mesh). Analytical thin-layer chromatography (TLC) was performed on $20 \times 20 \mathrm{~cm}$ Merck silica gel $60 \mathrm{~F}_{254}$ aluminum plates. Doxorubicin (purity: >99\%) was obtained from Pharmacia (Perth, Australia).

\section{Plant material}

The plant of $P$. pulcher was collected from the cultivation experimental plot of the Laboratory of Natural Products, Institute of Bioscience, Universiti Putra Malaysia, Malaysia between June August of 2004 and 2005. A voucher specimen (No. SK 306/02) has been deposited at the Herbarium of the Institute of Biosciences, Universiti Putra Malaysia, Malaysia.

\section{Extraction and isolation}

The air dried and ground roots of $P$. pulcher $(1.2 \mathrm{Kg})$ were sequentially extracted with dichloromethane (DCM), ethyl acetate (EtOAc) and methanol $(\mathrm{MeOH})$ by cold maceration $(3 \mathrm{X} 1 \mathrm{~L}$ for each solvent) and then the solvent portion was filtered and concentrated using a rotary evaporator to yield $9.0,3.0$ and $12.0 \mathrm{~g}$ of extracts, respectively. The DCM extract $(9.0 \mathrm{~g})$ was subjected to column chromatography over silica gel $(250 \mathrm{~g})$ with a gradient mobile system of hexane:EtOAc (100:0) to EtOAc:MeOH (75:25) to obtain 16 fractions. Fraction 2 was further subjected to silica gel column chromatography employing hexane: $\mathrm{CH}_{2} \mathrm{Cl}_{2}$ (100:0 to $\left.0: 100\right)$ to give 40 subfractions (designated as 2.1-2.40). Subfractions from 2.17 to 2.31 were combined based on their TLC profile and purified to afford 3a-acetoxyl-25-hydroxyolean-12-en-28-oic acid (1) (25 mg). Fraction 6 was subjected to silica gel column chromatography employing hexane:EtOAc (100:0 to $0: 100)$ as eluents to yield 32 subfractions (designated as 6.1-6.32). Subfraction 6.14 was further purified to afford glochidone (2) (14 mg). Fraction 7 gave 20 subfractions upon subjecting it to silica gel column chromatography using hexane:DCM (50:0 to $0: 100)$ as eluent in step gradient manner. Subfraction 7.8 was further purified by column chromatography using $15 \%$ EtOAc in hexane as eluting solvent to yield 12(13)-dehydro-3 $\alpha$-acetoxyolean-28-oic acid (3) (9 mg). Upon silica gel column chromatography with DCM:EtOAc (100:0 to 0:100) as eluents, fraction 10 gave 18 subfractions. Further purification on column chromatography (silica gel, DCM:MeOH, 100:0 to 90:10), fraction 10.9 gave 27 subfractions, from which subfraction 10.9.8 yielded lupanyl acetate (4) (5 mg). Purification of fraction 12 using column chromatography (silica gel, hexane:EtOAc, 0:100 to 100:0) yielded glochidonol (5) (12 mg).

\section{2(13)-Dehydro-3 $\alpha$-acetoxyolean-28-oic acid (3)}

White amorphous solid; $\mathrm{mp} 215-217^{\circ} \mathrm{C} ;[\alpha]_{\mathrm{D}}^{25}+0.38\left(\mathrm{c} 0.02, \mathrm{CHCl}_{3}\right)$; UV $\left(\mathrm{CHCl}_{3}\right) \lambda_{\max }(\log \varepsilon): 240$ (3.75), $245(3.45) \mathrm{nm} ; \mathrm{IR}(\mathrm{KBr}) \mathrm{v}_{\max } \mathrm{cm}^{-}$ ${ }^{1}: 3433,2944,2373,1745,1688,1459,1243,978,880,619 ;{ }^{1} \mathrm{H}$ $\operatorname{NMR}\left(\mathrm{CDCl}_{3}, 500 \mathrm{MHz}\right): \delta 4.82(1 \mathrm{H}, \mathrm{t}, J=3.0 \mathrm{~Hz}, \mathrm{H}-3 \beta), 2.56(1 \mathrm{H}$, $\mathrm{m}, \mathrm{H}-5), 2 . .43(1 \mathrm{H}$, brt, $\mathrm{H}-9), 2.19(1 \mathrm{H}, \mathrm{m}, \mathrm{H}-13), 2.05(3 \mathrm{H}, \mathrm{s}$, $\left.\mathrm{CH}_{3} \mathrm{CO}\right), 1.82(2 \mathrm{H}, \mathrm{m}, \mathrm{H}-2), 1.80(2 \mathrm{H}, \mathrm{m}, \mathrm{H}-1), 1.64(2 \mathrm{H}, \mathrm{m}, \mathrm{H}-6)$, $1.56(2 \mathrm{H}, \mathrm{m}, \mathrm{H}-15), 1.55(2 \mathrm{H}, \mathrm{m}, \mathrm{H}-22), 1.38(2 \mathrm{H}, \mathrm{m}, \mathrm{H}-7), 1.37(2 \mathrm{H}$, $\mathrm{m}, \mathrm{H}-16), 1.36(2 \mathrm{H}, \mathrm{m}, \mathrm{H}-21), 1.35(1 \mathrm{H}, \mathrm{m}, \mathrm{H}-18), 1.33(2 \mathrm{H}, \mathrm{m}, \mathrm{H}-$ 19), $1.31(2 \mathrm{H}, \mathrm{m}, \mathrm{H}-11), 1.30(2 \mathrm{H}, \mathrm{m}, \mathrm{H}-12), 1.12(3 \mathrm{H}, \mathrm{s}, \mathrm{H}-24)$, $1.06(3 \mathrm{H}, \mathrm{s}, \mathrm{H}-26), 1.03(3 \mathrm{H}, \mathrm{s}, \mathrm{H}-29), 1.01(3 \mathrm{H}, \mathrm{s}, \mathrm{H}-23), 0.96(3 \mathrm{H}$, $\mathrm{s}, \mathrm{H}-25), 0.93(3 \mathrm{H}, \mathrm{s}, \mathrm{H}-30), 0.90(3 \mathrm{H}, \mathrm{s}, \mathrm{H}-27) ;{ }^{13} \mathrm{C} \mathrm{NMR}(125 \mathrm{MHz}$, $\left.\mathrm{CDCl}_{3}\right): \delta 183.1$ (C-28), $172.8\left(\mathrm{CH}_{3} \underline{\mathrm{CO}}\right.$ ), 80.9 (C-3), 55.4 (C-5), 51.7 (C-9), 49.6 (C-8), 48.1 (C-2), 47.6 (C-18), 47.2 (C-17), 45.1 (C-19), 43.2 (C-14), 39.4 (C-1), 39.0 (C-13), 37.8 (C-4), 37.5 (C-10), 36.3 (C-7), 35.6 (C-16), 32.6 (C-22), 29.6 (C-20), 28.9 (C-21), 28.4 (C12), 28.0 (C-23), 27.4 (C-15), 23.0 (C-30), 22.0 (C-24), 21.5 $\left(\mathrm{CH}_{3} \mathrm{CO}\right), 21.0$ (C-11), 18.2 (C-6), 16.2 (C-26), 16.0 (C-25), 15.8 (C29), 14.3 (C-27); EIMS (pos. ion mode) $\mathrm{m} / \mathrm{z}(\%): 500[\mathrm{M}]^{+}(4), 482$ (10), 467 (20), 440 (18), 422 (12), 372 (20), 350 (30), 335 (12), 288 (12), 219 (28), 203 (28), 189 (60), 176 (100), 147 (74), 133 (30), 107 (38), 95 (36), 81 (26), 79 (18); HREIMS m/z: $500.3872[\mathrm{M}]^{+}$ (calc. 500.3867 for $\mathrm{C}_{32} \mathrm{H}_{52} \mathrm{O}_{4}$ ).

\section{Lupanyl acetate (4)}

White amorphous solid; $\mathrm{mp} 247-249^{\circ} \mathrm{C} ;[\mathrm{\alpha}]_{\mathrm{D}}^{25}-0.30\left(\mathrm{c} 0.02, \mathrm{CHCl}_{3}\right)$; UV $\left(\mathrm{CHCl}_{3}\right) \lambda_{\max }(\log \varepsilon): 240$ (3.75), 245 (3.45) nm; IR (KBr) $v_{\max } \mathrm{cm}$ 1: $2372,1735(\mathrm{C}=\mathrm{O}), 1450,1251,1024(\mathrm{C}-\mathrm{O}), 883,642,586 ;{ }^{1} \mathrm{H}$ $\operatorname{NMR}\left(500 \mathrm{MHz}, \mathrm{CDCl}_{3}\right): \delta 3.38(1 \mathrm{H}, \mathrm{dd}, J=11.2,4.1 \mathrm{~Hz}, \mathrm{H}-3), 2.43$ $(1 \mathrm{H}$, brt, $\mathrm{H}-9), 2.19(1 \mathrm{H}, \mathrm{m}, \mathrm{H}-13), 2.05\left(3 \mathrm{H}, \mathrm{s}, \mathrm{C}_{3} \mathrm{CO}\right), 1.93(1 \mathrm{H}$, $m, H-2 \beta), 1.80(2 H, m, H-1), 1.75(1 \mathrm{H}, \mathrm{m}, \mathrm{H}-2 \alpha), 1.66(1 \mathrm{H}, \mathrm{m}, \mathrm{H}-5)$, 
$1.64(2 \mathrm{H}, \mathrm{m}, \mathrm{H}-6), 1.57(2 \mathrm{H}, \mathrm{m}, \mathrm{H}-16), 1.55(2 \mathrm{H}, \mathrm{m}, \mathrm{H}-22), 1.38(2 \mathrm{H}$, $\mathrm{m}, \mathrm{H}-7), 1.36(4 \mathrm{H}, \mathrm{m}, \mathrm{H}-15, \mathrm{H}-21), 1.35(1 \mathrm{H}, \mathrm{m}, \mathrm{H}-18), 1.34(1 \mathrm{H}, \mathrm{m}$, $\mathrm{H}-20), 1.33(1 \mathrm{H}, \mathrm{m}, \mathrm{H}-19), 1.31(2 \mathrm{H}, \mathrm{m}, \mathrm{H}-11), 1.30(2 \mathrm{H}, \mathrm{m}, \mathrm{H}-12)$, $1.12(3 \mathrm{H}, \mathrm{s}, \mathrm{H}-24), 1.06(3 \mathrm{H}, \mathrm{s}, \mathrm{H}-26), 1.03(3 \mathrm{H}, \mathrm{s}, \mathrm{H}-29), 1.01(3 \mathrm{H}$, s, H-23), $0.98(3 \mathrm{H}, \mathrm{s}, \mathrm{H}-30), 0.96(3 \mathrm{H}, \mathrm{s}, \mathrm{H}-25), 0.93(3 \mathrm{H}, \mathrm{s}, \mathrm{H}-28)$, $0.90(3 \mathrm{H}, \mathrm{s}, \mathrm{H}-27) ;{ }^{13} \mathrm{C}$ NMR $\left(125 \mathrm{MHz}, \mathrm{CDCl}_{3}\right): \delta 171.8\left(\mathrm{CH}_{3} \underline{\mathrm{CO}}\right)$, 80.8 (C-3), 54.9 (C-5), 49.4 (C-9), 47.9 (C-18), 44.7 (C-19), 44.0 (C17), 43.1 (C-14), 41.0 (C-22), 39.8 (C-8), 38.6 (C-1), 38.0 (C-10,13), 37.5 (C-4), 35.8 (C-16), 34.3 (C-7), 30.2 (C-20), 29.2 (C-23), 27.6 (C-15), 27.2 (C-12), 23.8 (C-2), 22.8 (C-30), 22.0 (C-21), 21.6 $\left(\mathrm{CH}_{3} \mathrm{CO}\right), 20.6$ (C-11), 18.3 (C-6), 17.8 (C-28), 16.6 (C-24), 16.4 (C26), 16.2 (C-25), 15.5 (C-29), 14.7 (C-27); EIMS (pos. ion mode) $\mathrm{m} / \mathrm{z}(\%): 470[\mathrm{M}]^{+}(2), 422$ (12), 379 (8), 311 (10), 229 (54), 203 (28), 189 (30), 147 (46), 119 (68), 105 (80), 91 (100), 79 (60); HREIMS m/z: 470.4147 [M] (calc. 470.4126 for $\mathrm{C}_{32} \mathrm{H}_{54} \mathrm{O}_{2}$ ).

\section{Cytotoxic activity}

Microculture tetrazolium (MTT) cytotoxic assay was utilised to determine the cancer cell viability after addition of extracts or compounds. This assay is based on the ability of the dehydrogenase enzymes in living cells to convert soluble yellow MTT (into insoluble purple formazan) (Mosmann, 1983). The assay was carried out in the Laboratory of Pharmacotherapeutics, Department of Medicine, Faculty of Medicine and Health Sciences, Universiti Putra Malaysia.

Cancer cells MCF-7 (breast), NCl-H460 (non-small cell lung) and DU-145 (prostate) were grown in RPMI-1640 culture medium (Gibco, Auckland, New Zealand) supplemented with $10 \%$ heatinactivated foetal calf serum (PAA Laboratories, Linz, Austria), penicillin $(100 \mathrm{IU} / \mathrm{mL})$ and streptomycin $(100 \mu \mathrm{g} / \mathrm{mL})$ (Gibco, Auckland, New Zealand) in a humidified atmosphere with $5 \% \mathrm{CO}_{2}$ at $37^{\circ} \mathrm{C}$. The cells were subcultured using trypsin-EDTA every 3-4 days. Exponentially growing cells were plated in 96-well flat bottom microculture plates (TPP, Trasadingen, Switzerland) with cell numbers plated adjusted so that cells are subconfluent at the end of the assay. The cells were allowed to attach for about $24 \mathrm{~h}$ before the addition of extracts or isolated compounds. A stock concentration of $100 \mathrm{mM}$ or $100 \mathrm{mg} / \mathrm{mL}$ for each test agent was made up in DMSO. The working concentrations ranging from 1 to $1000 \mu \mathrm{M}$ or $0.1 \mu \mathrm{g} / \mathrm{mL}-100.0 \mu \mathrm{g} / \mathrm{mL}$ were obtained by serial dilution of stock in culture medium and $20 \mu \mathrm{L}$ of each of the concentration was added into the appropriate wells in four replicates to obtain final concentrations ranging from 0.1 to $100 \mu \mathrm{M}$. The control cells were treated with the highest concentration of DMSO $(0.1 \%)$ as vehicle control. The cells were exposed continuously to test agents for $96 \mathrm{~h}$. This was followed by addition of MTT (PhytoTechnology Laboratories, Kansas, USA) to a final concentration of $0.4 \mathrm{mg} / \mathrm{mL}$ per well and the cells were further incubated for $4 \mathrm{~h}$ to allow conversion of MTT. The resulting formazan crystals were dissolved with dimethysulfoxide (Fisher Scientific, Leicestershire, United Kingdom) and the absorbance of the purple formazan was read at $550 \mathrm{~nm}$ using a 96-well microplate reader (VERSAmax, Molecular Devices, California, United States of America). Dose-response curves were constructed to obtain the $50 \%$ inhibitory concentrations $\left(\mathrm{IC}_{50}\right)$ according to method of Jada et al. (2008).

\section{RESULTS AND DISCUSSION}

The investigation of phytochemicals of the roots of this species with cytotoxic activity led to the isolation of five triterpenes 1-5 (Figure 1).

Compound $\mathbf{4}$ is reported for the first time from a natural source while 1 and 3 are isolated for the first time from Euphorbiaceae family. Compounds 1, 2 and 5 were identified by comparison of their spectral data with the literature values, which supported the structures as $3 a-$ acetoxyl-25-hydroxyolean-12-en-28-oic acid (Chun et al., 2002) and, glochidone and glochidonol (Puapairoj et al., 2005), respectively. Although 12(13)-dehydro-3a-acetoxyolean-28-oic acid (3) was previously reported (Bohlmann et al., 1979), here we are representing the complete data for the first time.

Compound 4 was a white amorphous solid with $\mathrm{mp}$ $247-249^{\circ} \mathrm{C}$. The molecular formula was assigned as $\mathrm{C}_{32} \mathrm{H}_{54} \mathrm{O}_{2}\left(\mathrm{M}^{+} ; \mathrm{m} / \mathrm{z}\right.$ 470.4147) by HREIMS. The IR spectrum showed a carbonyl absorption band at $\mathrm{v}_{\max }$ $1735 \mathrm{~cm}^{-1}$ indicating the presence of an acetate group. This was further confirmed by a three protons signal at $\delta$ 2.05 in the ${ }^{1} \mathrm{H}$ NMR spectrum, which correlated with the carbon signals at $\delta 21.6\left(\mathrm{CH}_{3}\right)$ in $\mathrm{HSQC}$, and $\delta 171.8$ $(\mathrm{C}=\mathrm{O})$ in HMBC spectra. The ${ }^{13} \mathrm{C}$ NMR spectrum of 4 revealed 32 carbon signals, which were assigned by DEPT experiment as eight methyl, ten methylene, seven methine and six quaternary carbons. The ${ }^{1} \mathrm{H}$ NMR spectrum displayed signals for typical triterpenoid methyl groups at $\delta 1.12\left(\mathrm{CH}_{3}-24\right), 1.06\left(\mathrm{CH}_{3}-26\right), 1.03\left(\mathrm{CH}_{3}-29\right)$, $1.01\left(\mathrm{CH}_{3}-23\right), 0.98\left(\mathrm{CH}_{3}-30\right), 0.96\left(\mathrm{CH}_{3}-25\right), 0.93\left(\mathrm{CH}_{3}-\right.$ 28), and $0.90\left(\mathrm{CH}_{3}-27\right)\left[\delta_{\mathrm{C}} 16.6,16.4,15.5,29.2,22.8\right.$, $16.2,17.8$, and 14.7, respectively, according to the HSQC experiment.

The ${ }^{1} \mathrm{H}$ NMR spectrum also showed a signal at $\delta 3.38$ $\left(1 \mathrm{H}, \mathrm{dd}, J_{\mathrm{ax} / \mathrm{ax}}=11.2, J_{\mathrm{ax} / \mathrm{eq}} 4.1 \mathrm{~Hz}\right)$ due to coupling with two methylene protons at $\mathrm{CH}_{2}-2$, was attributed to $\mathrm{H}-3$, and it was confirmed by its $\mathrm{HMBC}$ correlations with $\delta_{\mathrm{C}}$ 23.8 (C-2), 37.5 (C-4), 54.9 (C-5), 29.2 (C-23), 16.6 (C$24)$ and $171.8(\mathrm{C}=\mathrm{O})$ (Figure 2). The chemical shift of this proton showed that the stereochemistry was assignable to either axial $(\alpha)$ or equatorial $(\beta)$ position. The values of the chemical shift couplings (diaxial $(11.2 \mathrm{~Hz}$ ) and axial/equatorial $(4.1 \mathrm{~Hz})$ interactions suggested that $\mathrm{H}-3$ was in an axial $(\alpha)$ position, hence the acetate was in an equatorial ( $\beta$ ) position. On the basis of above spectroscopic analyses, 4 was confirmed as lupanyl acetate, which was formerly reported as a synthetic product from lupenyl acetate (Heilbron et al., 1938). However, this is the first report of its occurrence as a natural product.

DCM extract of the roots of $P$. pulcher was most potent and its activity was more selective towards MCF-7 cells when compared with DU-145 and H460 (non-small cell lung) cell lines (Table 1). The cytotoxic activity of the isolated compounds 1-5 was evaluated in vitro against the same three human tumour cell lines as above. Compound 1 exhibited cytotoxic activity against MCF-7 and DU-145 cell lines with $\mathrm{IC}_{50}$ values of 26.4 and 39.9 $\mu \mathrm{g} / \mathrm{mL}$, respectively, but it failed to exhibit activity against H460 cells (Table 2). Compound 5 showed cytotoxic activity against MCF-7, DU-145 and $\mathrm{H} 460$ cell lines with 

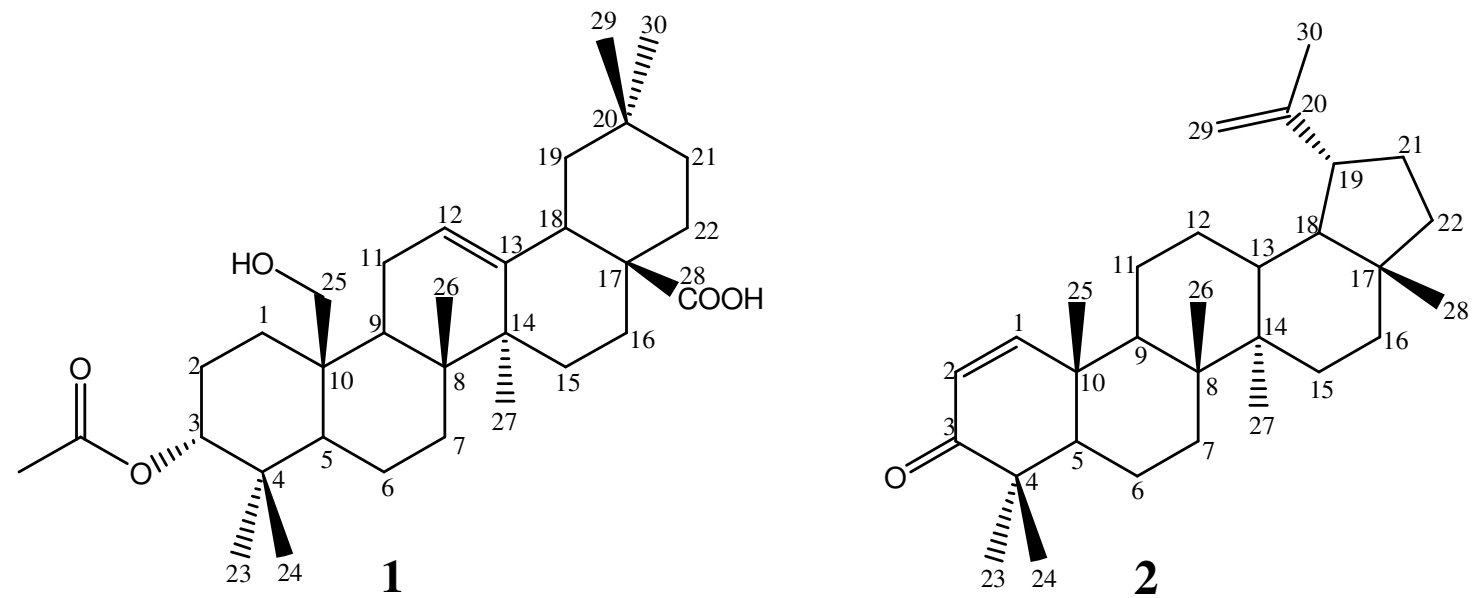<smiles>C[C]1C2CCC3(C)C(CCC4C5C[C@@H](C)CC[C@]5(C(=O)O)CC[C@@]43C)[C@@]2(C)CC[C@@H]1OC(C)=O</smiles><smiles>C[C]1C2CC[C@]3(C)C(CCC4C5[C@H](C(C)C)CC[C@]5(C)CC[C@@]43C)[C@@]2(C)CC[C@@H]1OC(C)=O</smiles><smiles>C=C(C)[C@H]1CC[C@]2(C)CC[C@]3(C)C(CCC4[C@@]5(C)C(CC[C@]43C)C(C)(C)C(=O)C[C@H]5O)C12</smiles>

Figure 1. Chemical structures of compounds 1-5 from the roots of Phyllanthus pulcher.

the $\mathrm{IC}_{50}$ values of $7.5,13.4$ and $9.5 \mu \mathrm{g} / \mathrm{mL}$, respectively (Table 2). Among all the isolated compounds only compound $\mathbf{5}$ exhibited cytotoxic activity against H460cells (Table 2). Compounds 2, 3 and 4 failed to exhibit cytotoxic effect against all the tested cell lines (Table 2). Compound 5 had stronger activity against MCF-7 cells by nearly 3-fold compared with 1 .
Testing the compounds against the three cancer cell lines provided insights into the selectivity profile. This is vital as selectivity could be used to predict the extent of toxicity to normal tissues. Compound 5, which was identified as lupane-type triterpenoid, was the most potent agent against the panel of three cell lines tested and rewardingly the compound exhibited selectivity 


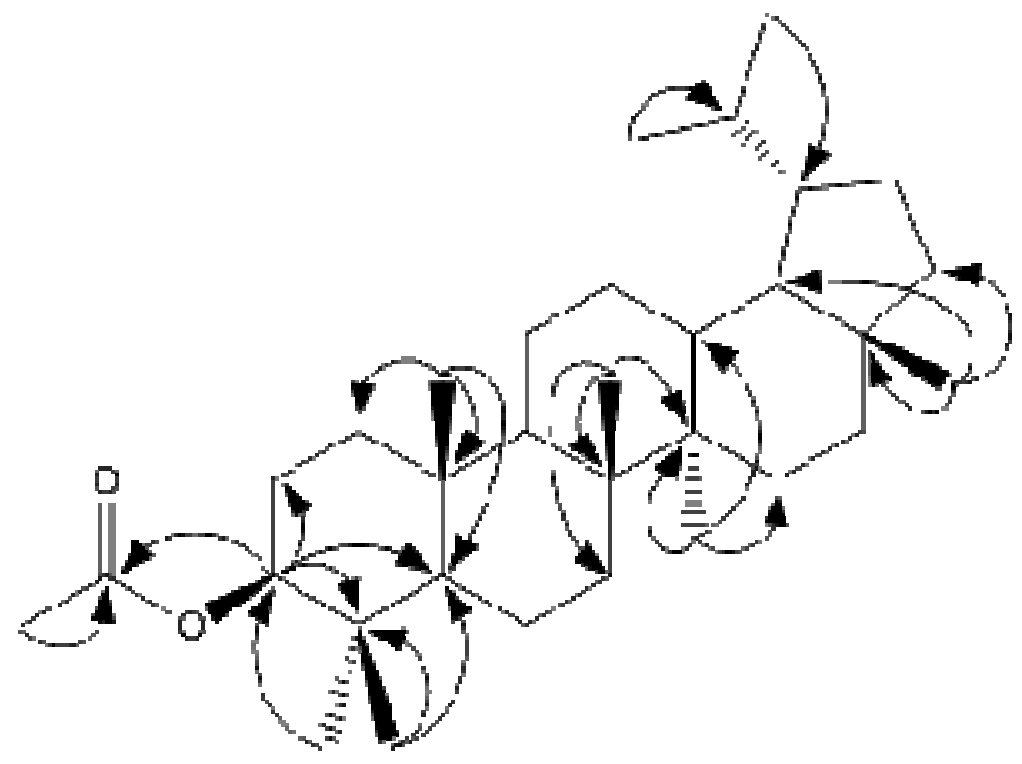

Figure 2. Selected HMBC correleations of 4.

Table 1. Cytotoxicity of solvent extracts of $P$. pulcher roots in breast (MCF-7), prostate (DU-145) and lung (H460) tumour cell lines.

\begin{tabular}{lccc}
\hline \multirow{2}{*}{ Extract } & \multicolumn{3}{c}{$\mathrm{IC}_{\mathbf{5 0}}(\boldsymbol{\mu \mathrm { g }} / \mathbf{\mathrm { mL }})$} \\
\cline { 2 - 4 } & $\mathbf{M C F}-\mathbf{7}$ & $\mathbf{D U}-\mathbf{1 4 5}$ & $\mathbf{H 4 6 0}$ \\
\hline DCM & $9.8 \pm 1.0$ & $13.4 \pm 1.3$ & $26.0 \pm 2.0$ \\
EtOAc & $18.6 \pm 3.4$ & $20.8 \pm 2.6$ & $42.0 \pm 4.1$ \\
$\mathrm{MeOH}$ & $>100$ & $>100$ & $>100$ \\
\hline
\end{tabular}

Values were determined after $96 \mathrm{~h}$ by MTT assay; $\mathrm{IC}_{50}$ values are mean $\pm \mathrm{SD}$ obtained from 3 independent experiments.

Table 2. Cytotoxicity of isolated compounds (1-5) in cancer cell lines.

\begin{tabular}{cccc}
\hline \multirow{2}{*}{ Compound } & \multicolumn{3}{c}{ IC $_{50}(\boldsymbol{\mu M})^{\mathbf{a}}$} \\
\cline { 2 - 4 } & MCF-7 & DU-145 & H460 \\
\hline $\mathbf{1}$ & $51.5 \pm 2.8\left(26.4 \pm 1.4^{*}\right)$ & $77.8 \pm 1.8\left(39.9 \pm 0.9^{*}\right)$ & $>100$ \\
$\mathbf{2}$ & $>100$ & $>100$ & $>100$ \\
$\mathbf{3}$ & $>100$ & $>100$ & $>100$ \\
$\mathbf{4}$ & $>100$ & $>100$ & $>100$ \\
$\mathbf{5}$ & $17.1 \pm 1.2\left(7.5 \pm 0.5^{*}\right)$ & $30.5 \pm 1.6\left(13.4 \pm 0.7^{*}\right)$ & $21.7 \pm 2.4\left(9.5 \pm 1.0^{*}\right)$ \\
Doxorubicin $^{\mathrm{b}}$ & $0.01 \pm 0.001$ & $0.07 \pm 0.02$ & $0.12 \pm 0.05$ \\
\hline
\end{tabular}

${ }^{a}$ Values are mean \pm SD obtained from 3 independent experiments; ${ }^{b}$ Doxorubicin was used as a positive control in this study.

${ }^{*}$ Values in $\mu \mathrm{g} / \mathrm{mL}$ and were determined after $96 \mathrm{~h}$ by MTT assay.

towards MCF-7 cells $\left(\mathrm{IC}_{50} 17.1 \mu \mathrm{M}\right)$. Search of the literature revealed that lupane-type triterpenoids such as lupeol possess in vitro antitumour, antiangiogenic and apoptosis inducing properties in cancer cells (Moriarty et al., 1998; You et al., 2003; Aratanechemuge et al., 2004) which is in accordance with our findings. Interestingly, betulinic acid, another lupane-type triterpenoid with good in vitro anticancer activity was reported to be less cytotoxic to normal cells such as normal human astrocytes and melanocytes (Cichewicz and Kouzi, 2004) Basing on the above evidences, we propose that compound $\mathbf{5}$ would be less toxic against normal tissues. 
However, the most appropriate strategy to assess the toxicity of a compound to normal tissues of the whole body is through evaluation in animal models. Therefore, in vivo toxicity study would be advantageous.

By comparing the $\mathrm{IC}_{50}$ values (in $\mu \mathrm{g} / \mathrm{mL}$ ) of $\mathrm{DCM}$ extract with that of compounds $\mathbf{1}$ and $\mathbf{5}$, it would seem obvious that the cytotoxicity exhibited by DCM extract could mainly be due to the presence of $\mathbf{5}$ as the major compound in the extract. However, there may exist minor bioactive compounds such 1 in the DCM extract which could have also contributed to the cytotoxicity of the extract.

\section{Conclusion}

The DCM extract of roots of $P$. pulcher displayed a strong cytotoxic activity against MCF-7, DU-145 and H460 cell lines, with $\mathrm{IC}_{50}$ values of $9.8,13.4$ and $26.0 \mu \mathrm{g} / \mathrm{mL}$, respectively. This prompted us to perform chemical investigation to identify the bioactive compounds responsible for the cytotoxicity of the extract which led to the isolation of five triterpenoids. We found that lupanetype triterpenoids accumulated in the roots of this species with 1 and 5 being the cytotoxic compounds. Upon a closer examination to relate the bioactivity with that of the compounds' chemical structures revealed both compounds possessed a free hydroxyl moiety. Such a feature is also apparent among the biologically active lupanetype triterpenoids such as betulinic acid and lupeol. Hence, we strongly believe this could be an important pharmacophore to be considered for cytotoxicity in this class of compounds. Comparison of the structures of the compounds 2 and 5 bear close resemblance to each other. The only notable difference is the additional hydroxyl group in $\mathbf{5}$, which might have been derived biosynthetically from the hydroxylation of 2 . In this investigation, $\mathbf{5}$ has been identified as the most promising compound due to its selective cytotoxicity against breast cancer cells.

\section{ACKNOWLEDGMENT}

The authors wish to thank the Ministry of Science, Technology and Innovation (MOSTI) of Malaysia for funding this project through the Intensification of Research in Priority Areas (IRPA) grant 01-02-04-0088.

\section{REFERENCES}

Aratanechemuge $\mathrm{Y}$, Hibasami $\mathrm{H}$, Sanpin K, Katsuzaki H, Imai K, Komia $T$ (2004). Induction of apoptosis by lupeol isolated from mokumen (Gossampinus malabarica L. Merr) in human promyelotic leukemia HL-60 cells. Oncol. Rep., 11: 289-292.

Bagalkotkar G, Sagineedu SR, Saad MS, Stanslas J (2006). Phytochemicals from Phyllanthus niruri Linn. and their pharmacological properties: A review. J. Pharm. Pharmacol., 58: 15591570.

Bila B, Gedris ET, Herz W (1996). Niruroidine, a norsecurinine-type alkaloid from Phyllanthus niruroides. Phytochemistry, 41: 1441-1443.

Bohlmann F, Zdero C, Ziesche J (1979). Neue Flavone und Phloroglucin-derivate aus Helichrysum herbaceum und Helichrysum chrysargyrum. Phytochemistry, 18: 1375-1378.

Burkill IH (1935). A dictionary of the economic products of the Malay Peninsula; Art Printing Works: Kuala Lumpur, Malaysia, pp. 17481749.

Chang CC, Lien YC, Liu KCSC, Lee SS (2003). Lignans from Phyllanthus uranaria. Phytochemistry, 63: 825-833.

Chun L, Youfu S, Yuru S (2002). A new triterpene from the fruits of Liquidambar formosana Hance-Lulutong. J. Chin. Pharmaceut. Sci., 11: 1-4.

Cichewicz RH, Kouzi S (2004). Chemistry, biological activity and chemotherapeutic potential of betulinic acid for the prevention and treatment of cancer and HIV infection. Med. Res. Rev., pp. 90-114.

Eldeen IMS, Seow EM, Abdullah R, Sulaiman SF (2010). In vitro antibacterial, antioxidant, total phenolic contents and anti-HIV-1 reverse transcriptase activities of extracts of seven Phyllanthus sp. S. Afr. J. Bot., (in press).

Foo LY (1995). Amariinic acid and related ellagitannins from Phyllanthus amarus. Phytochemistry, 39: 217-224.

Heilbron G, Spring G, Kennedy J (1938). The unsaturated centre of the triterpene alcohol lupeol. J. Chem. Soc., pp. 329-334.

Houghton PJ, Woldemariam TZ, O'shea S, Thyagarajan SP (1996). Two securinega-type alkaloids from Phyllanthus amarus. Phytochemistry, 43: 715-717.

Jada SR, Matthews C, Saad MS, Hamzah AS, Lajis NH, Stevens MFG, Stanslas J (2008). Benzylidene derivatives of andrographolide inhibit growth of breast and colon cancer cells in vitro by inducing G1 arrest and apoptosis. Brit. J. Pharmacol., 155: 641-654.

Lee SS, Lin MT, Liu CL, Lin YY, Liu KCSC (1996). Six lignans from Phyllanthus myrtifolius. J. Nat. Prod., 59: 1061-1065.

Matsunga S, Tanaka R, Takaoka, Y, In Y, Ishida T, Rahmani M, Ismail HBM (1993). 26- nor-D: A friedooleanane triterpenes from Phyllanthus watsonii. Phytochemistry, 32: 165-170.

Moriarty DM, Huang J, Yancey CA, Zhang P, Setzer WN, Lawton RO, Bates RB, Caldera S (1998). Lupeol is the cytotoxic principle in the leaf extract of Dendropanax c.f. querceti. Planta Med., 64: 370-372.

Mosmann T (1983). Rapid colorimatric assay for cellular growth and survival: Application to proliferation and cytotoxicity assays. J. Immunol. Methods, 65: 55-63.

$\mathrm{Ng} \mathrm{KW}$, Salhimi SM, Majid AMSA, Chan KL (2010). Anti-angiogenic and cytotoxicity studies of some medicinal plants. Planta Med., 76(9): 935-940.

Puapairoj P, Naengchomnong W, Kijjoa A, Pinto MM, Pedro M, Nascinento MSJ, Silva AMS, Herz W (2005). Cytotoxic activity of Lupane-type triterpenes from Glochidion sphaerogynum and Glochidion eriocarpum two of which induce apoptosis. Planta Med., 71: 208-213.

Unander DW, Webster GL, Blumberg BS (1990). Records of usage or assays in Phyllanthus (Euphorbiaceae): I. Subgenera Isocladus, Kiranelia, Cicca and Emblica. J. Ethnopharmacol., 30: 233-264.

Unander DW, Webster GL, Blumberg BS (1992). Usage and bioassays in Phyllanthus (Euphorbiaceae): A compilation III. The subgenera Eriococcus, Conami, Gomphidium, Botryanthus, Xylophylla and Phyllanthodendron, and a complete list of the species cited in the three-part series. J. Ethnopharmacol., 36: 103-112.

You YJ, Nam NH, Kim Y, Bae KH, Ahn BZ (2003). Anti-angiogenic activity of lupeol from Bombax Ceiba. Phytother. Res., 17: 341-344.

Zhang YJ, Tanaka T, Iwamoto Y, Yang CR, Kuono I (2001). Novel sesquiterpenoids from roots of Phyllanthus emblica. J. Nat. Prod., 64: 870-873.

Zhang YJ, Abe T, Tanaka T, Yang CR, Kouno I (2002). Two new acylated flavanone glycosides from the leaves and branches of Phyllanthus emblica. Chem. Pharm. Bull., 50: 841-843. 